\title{
Bioclimatic Performances of Traditional Straw Construction in Italy and in Portugal
}

\author{
By Nicolina Mastrangelo* \\ Dora Francese \\ Paulo Mendonca ${ }^{+}$ \\ Francisca Amorim ${ }^{\dagger}$
}

Technological innovation in envelope solutions integrate design ideas with performance levels, by investigating their potential, by creating a link between creative act and productive moment. New artificial materials are not the sole products meant to achieve sustainable solutions: lately a number of old materials - straw, stone, rammed earth - are becoming again updated for sustainability, zero waste production, bioclimatic behaviour and comfort and health, besides being economy and locally available.

Their great potential, as envelope elements is investigated in this paper, through a bioclimatic comparison between cases from Italy and from Portugal. Italian example is "Casone", typical of Venetian neighbourhood, Portuguese is fisherman dwelling from Carrasqueira village (Lisbon).

Promotion of vegetable materials can switch on processes of virtuous management of agricultural by-products, and produce environmental benefits for local regions. Real potential of vegetable materials as sustainable products for new constructions can be assessed.

Keywords: Eco-sustainable performances, Local resources straw, Traditional technologies.

\section{Introduction}

Many designers, thinking that re-employing poor materials in architecture was a nostalgic revival, usually undervalue the peculiarities of these products. Although the Italian building context is today characterized by highly industrialized products and semi-worked materials, this is fruit of a very recent productive process. The local traditional technologies are instead expression of an artisan process, where pre-production and on-site activity were almost contemporary stages. The materials employed in the building sector coincided with the local availability: mud, timber, stone, vegetables were the prime

\footnotetext{
${ }^{*}$ Ph.D. Student, Department of Architecture, University Federico II Naples, Italy.

${ }^{\ddagger}$ Professor, University Federico II, Italy.

${ }^{+}$Associate Professor, University of Minho School of Architecture, Lab2PT Research Centre, Portugal.

${ }^{\dagger}$ University of Minho School of Architecture, Lab2PT Research Centre, Portugal.
} 
matter set in use. The architecture involved elements and materials with high indexes of naturality. The architectural language underlined the place identity, whilst the ecosystemic balance between fabric and context provided built volumes integrated and harmonized with the site characteristics (May and Reid 2010). Among the building typologies, strictly linked to the local resources, some notable constructions are found in Italy such as: the Puglia's Trulli, the Venetian Casoni, the rammed earth residences in Sardinia and Abruzzo, the tufa stone houses in Campania, and others in Portugal such as the Carrasqueira huts. By achieving the ownership of this material/formal know-how, typical of the rural architecture, it will be possible to propose building systems at reduced ecological footprint, so enhancing the employment of poor materials. Nonetheless today it is difficult to introduce again into the construction such local and poor materials, as well as non-industrialized productive processes: the standard procedures of building factories, the use of oil derived products, the slower on-site process and the complex pre-production of the prime matter had led to the abandonment of the ancient technologies and materials. By pursuing the sustainable design, new perspectives are opened for these materials: for example many substances which in the past arranged the fabric envelope, such as the canes or the hemp, are today employed as insulating system for the external coating. Among those materials, the straw has been discovered as a very sustainable and insulating material. In each stage of the life cycle, this material overpasses greatly any other modern product.

\section{Materials and Methods}

Through a review of the literature sources the studies and the analyses were carried on by means of some case-studies (the ancient typology of the Venetian Casoni - Country and the Venetian Lagoon; the Portuguese vegetable roof and stone walls typologies. Today in Italy and in Portugal the new houses in straw are a few, in comparison with other European countries; while the rammed earth is usually employed as plaster or conservative maintenance. The greater obstacle for the application of these materials is due to the absence of specific standards. In the United Kingdom the innovation of the straw as building material has led to a number of experimental architectures. These products have on one hand great potential of arrangement, and on the other hand they present a life cycle with few emissions and few resources' consumption in the production stage, whilst on-site and operation stages also provide low environmental impact. By means of the mentioned case-studies, the bioclimatic performances of the straw have been investigated, so as to promote again the use of this material, which is low-cost, low-tech and lowcarbon: at the same time during the management of the country wastes', the interaction between the architecture and the agriculture can ensure the insert of a sustainable virtuous chain in the building and productive sector. 
The Straw Roofs in Italy: the Case Study of the Venetian Casoni

The technology of the straw roofs is not widely diffused in Italy; the use of this material for the application as superior protection can be mainly found in the North Italian regions, in particular in Piemonte, Lombardia, Veneto and Trentino Alto Adige.

The here proposed case-study is that of the Venetian Casoni, whose main characteristic is the structure of hut, built with bunches of marsh cane (Phragmites Australi) and straw (made up with both grain's or other cereal's sticks, with leaves and small trunks of pond grass).

The choice of employing these poor materials is linked to the wide availability and easy malleability in the stage of pre-production.

The main labor which proceeds the set-on-site operations usually was the following: gathering canes, by choosing the stems with the smallest diameter; collecting stems in mannelli $i^{1}$; cutting bunches of vegetable fibers according to a constant length of around $90 \mathrm{~cm}$ (Figure 1).

Figure 1. Production Stage of the Roof Mantle of the Casone

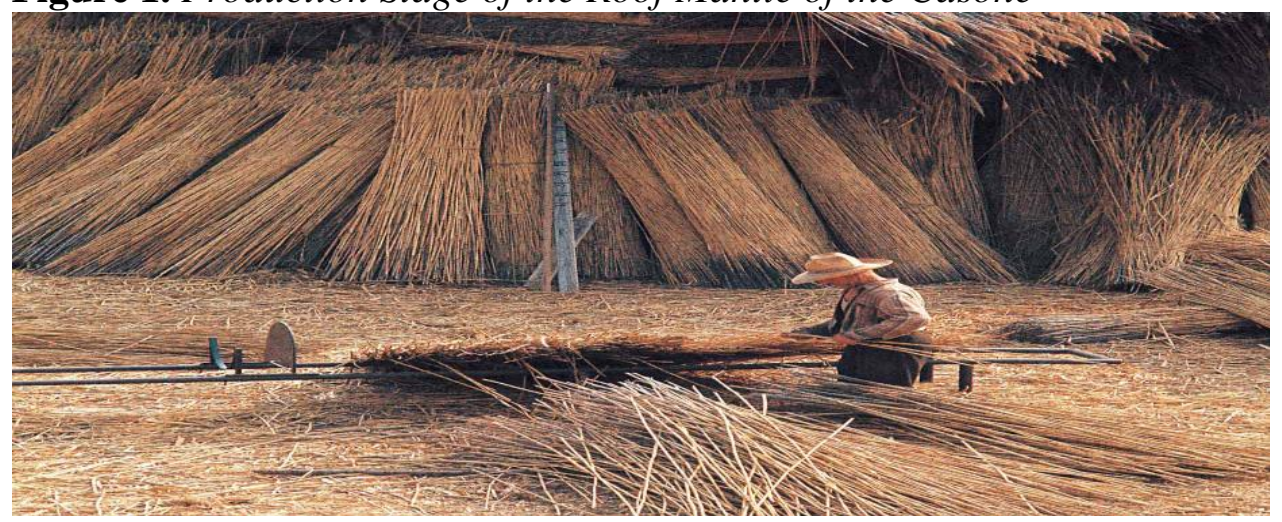

Source: Franzin 2004.

The term Casone usually denotes two building typologies, the Laguna (Lagoon) and the Country one, whose differences are clearly those of localization and users, fishermen or countrymen.

The transfer of the users' requirement creates formal, technological and volumetric differences. Historically these constructions date 4 century B. C., when along the Venetian coast the fishermen were used to have their house built by the Casoniere (the Casone maker).

\footnotetext{
${ }^{1}$ A small bunch of ears, grass, straw, and so on (Italian Garzanti Dictionary).
} 


\section{Territorial Distribution of the Casoni}

The analysis of the territorial context in which these singular constructions arise, shows that, nevertheless the modesty of the materials and the technological ease employed for their construction, the Casoni are the architectural elements that better represent the identity of the place in which they arise. In fact the aspect difference corresponds symbolically to the variable link of fabric with place.

Dwellings in the lagoon, mainly distributed along the Venetian coast (Figure 2b), present an aspect that reminds primordial format of temporary shelters, in other words the hut. Country kind, typical of the more internal lands of Padua (Figure 2a), are instead made up with envelope walls and tall roof, expressing not only the roots between earth and countryman, but also and mainly the major stability of construction.

A detailed and concrete counting of their location within the territory is somehow complex and articulated, but mainly Lagoon Casoni were in a greater number than those of country: what demonstrates also the fact that they were better constructed and thus better conserved. There are in fact "... still existing in between the Piave and the Tagliamento [two local rivers] more than a hundred Casoni" (Franzin 2004).

Figure 2. Sites of Casoni: the Country Casoni

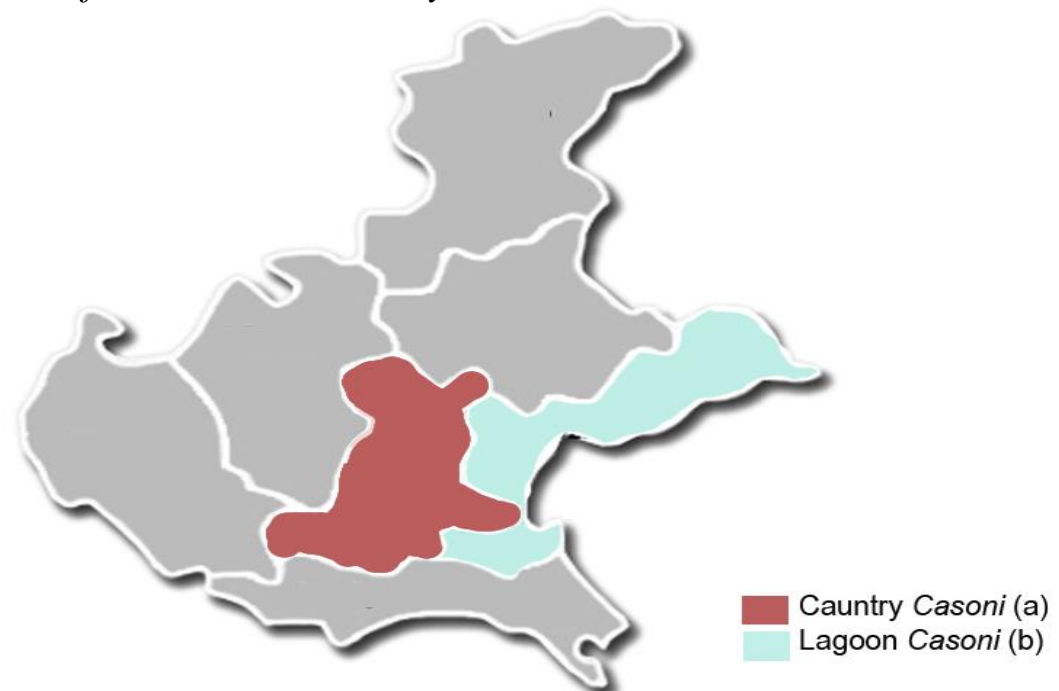

a. in the district of Padua and the Lagoon Casoni

b. in Carole and Bidione (North_East) and in Cavarzese (South-West)

Source: Prepared by N. Mastrangelo.

\section{Construction Technology of Lagoon Casoni}

The original structure of the Casone is made up as a hut with a four-angled roof with beams, while along the slopes, a number of tilted secondary beans were located with a regular inter-axe, which are called atole. The latest have the function of supporting the secondary carpenter system of stretturi and 
sottistutti, that were made as a grid of willow's and poplar's small branches, over which some bunches of canes or straw create the roof mantle (Figure 3).

Figure 3. Structural Elements of Casone

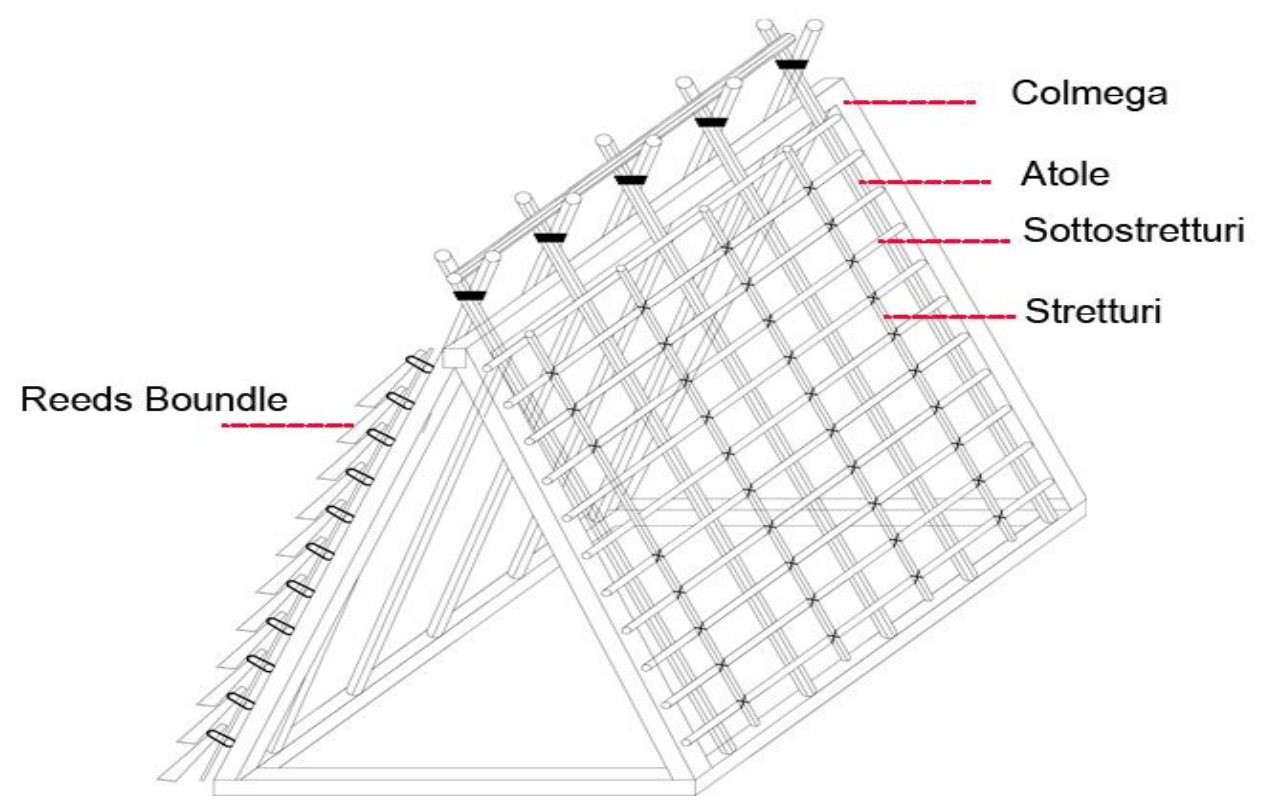

Source: Prepared by N. Mastranglo.

The mannelli are applied on site by joining bunches to this substructure of vegetable fibers; the arrangement of bunches along the roof slopes previews flowers formation on the top; these elements are applied by overlap in the connection points between one bunch and another.

The top element of roof is realized with some braided straw with the task of sealing the whole so as to avoid water infiltration (Tieto 1979). The construction of this dense roof mantle with vegetable fiber guarantees the envelope's thermal comfort, while also the strong slope of the tilted roof can expel rapidly the water and reduce the hazard for construction material's decay process (Figure 4).

Figure 4. The Structural Model of the Roof

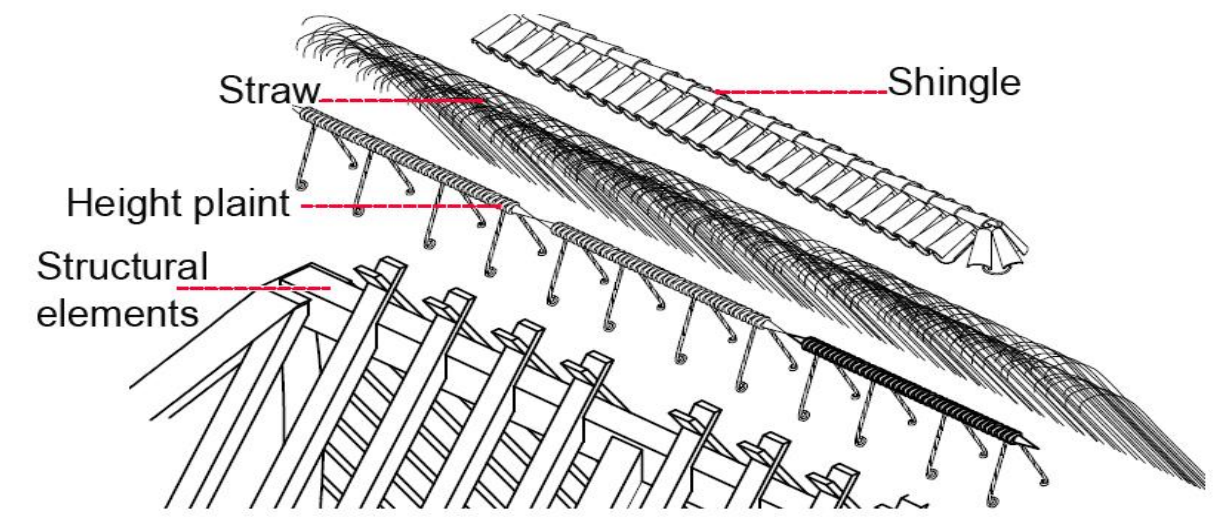

Source: Cipullo 2013. 
To this primordial typological format, upon years, a new technological solution has been adopted. In this new model the Casone roof has not the base at the ground floor, but at three meters of height, for the presence of the closing wall which was firstly made in vegetable material and later on in clay bricks. This new way of constructing was popular and gave birth to a great number of Lagoon Casoni, which do not present the tilted roof - still in vegetable materials - at the ground level but on top of a wall.

Since the Casone construction adopted an empirical know-how, it presents, from the dimensional viewpoint, some proportional rules, according to the following prescriptions:

- The length should be two times the width;

- The height and width should be equal to half of the length.

The more diffused sizing for the Lagoon Casoni includes usually some elements of elliptic or rectangular shape, of six meters high with the longitudinal axe of eight meters and the traversal one of six metres.

\section{Construction Technology of Country Casoni}

Since the research aim is a comparison between the bioclimatic performances of the two typologies (Figure 6), then it is fundamental to investigate also the construction technology of Country Casoni.

The conceiving matrix of the country type is different from the lagoon one: the stability and permanence characters of country Casone counteract to the transient character of the lagoon one, according to the typical life style of the country users. The need of occupying a inhabiting space all over the year and with the whole family created some transformations of the traditional model of the lagoon Casone, so leading to a more complex and articulated dwelling.

The main evolutions of the country Casoni can be summarized in the following aspects:

- formal image of the construction;

- introduction of perimeter walls and roof structure, which started from three meters rather than from the ground floor;

- new plan system, with the development of more and nearby spaces, according to the functional uses of nightly, daily and service zones (stable and the equipment recovery);

- introduction of chimney. 
Figure 6. Plan and Elevation of the Two Types of Huts
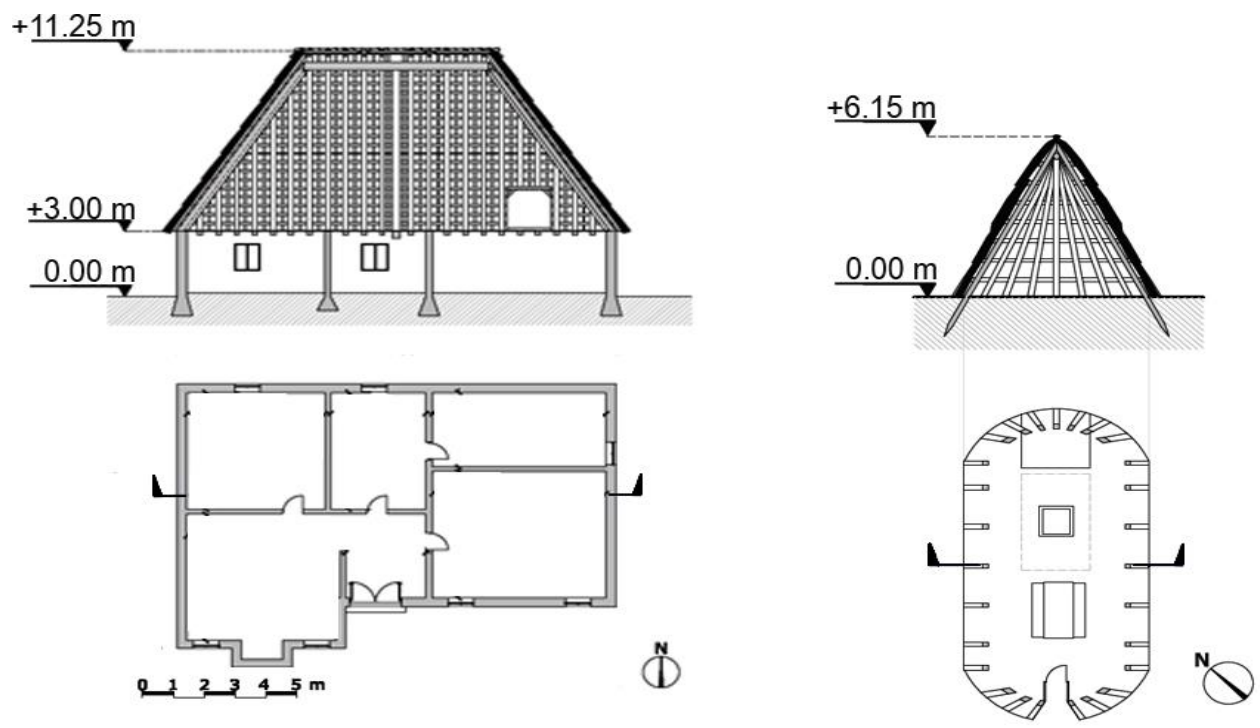

Source: Cipullo 2013.

In substance the technological innovation proposed in this dwelling typology is more complex and articulated than that of the lagoon Casoni. For example the envelope wall, originally made up in vegetable material, has been improved into raw bricks, while the internal partitions are in "Torchis" ${ }^{2}$ (Figure 7-8).

Figure 7. Plan of the Country Casone

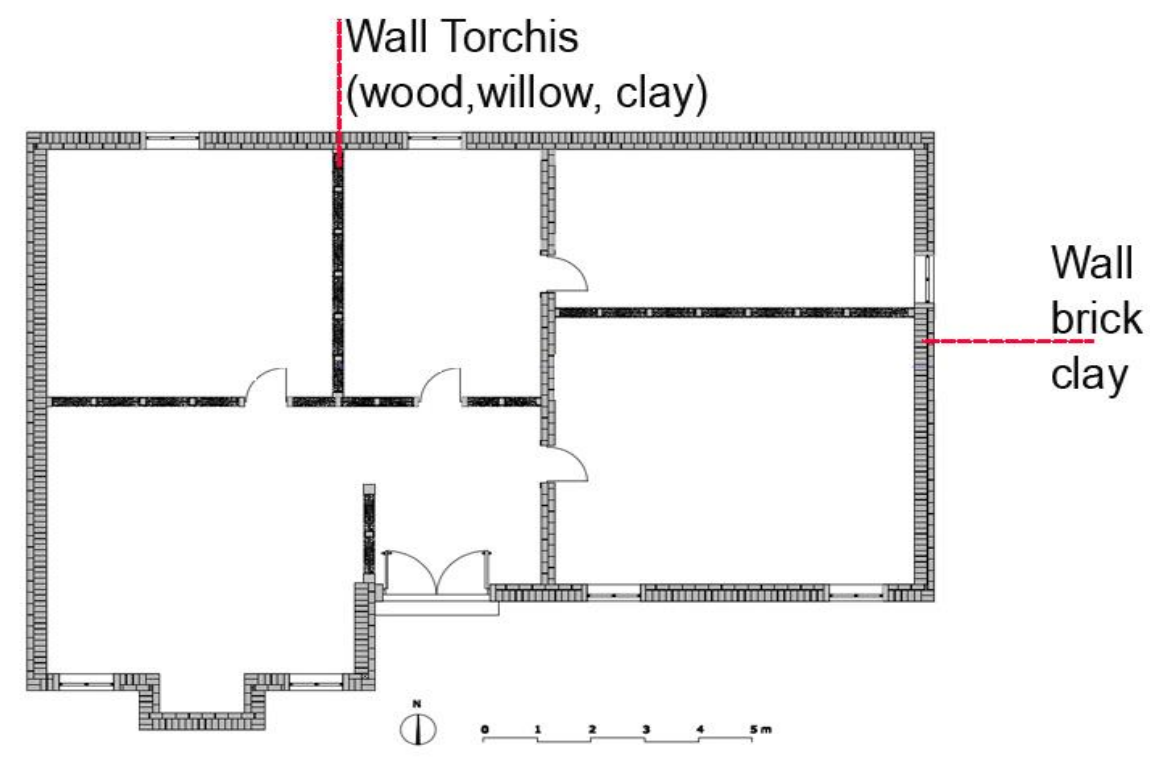

Source: Cipullo 2013.

${ }^{2}$ The technology of the Torchis, with a timber structure, a finishing with the willow wood and a clay plaster layer. 
Figure 8. Walls of the Country Typology

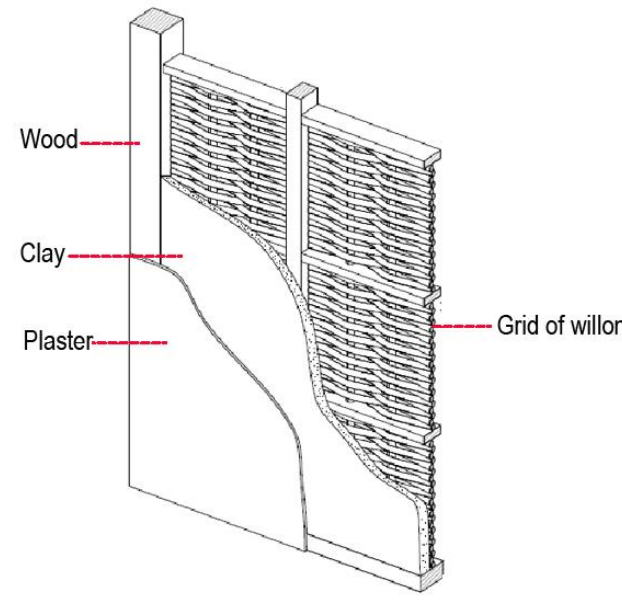

a. Internal Partition in Torchis

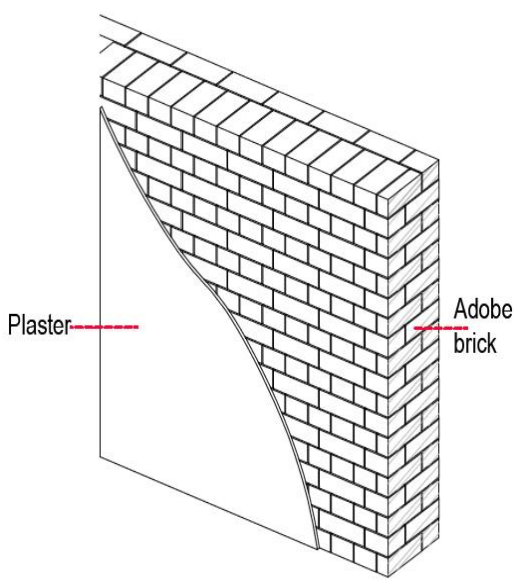

b. External Wall

Source: Cipullo 2013.

Finally introduction of chimney ${ }^{3}$ along the external perimeter of the south facade was close to the entrance to the residential units. The plan distribution follows a spiral layout, while the core of the building system is the entrance, access to any other room. Also the height of the house changed till twelve meters. Although the activities are always run at the ground floor, the rise of the roof can allow to recuperate the space under roof as a barn.

\section{The Straw Buildings in Portugal: The Case Study of Carrasqueira}

In Portugal, straw in traditional buildings is used according to three kinds:

a. vegetable roof and stone walls [the circular plan and conical thatch coverage was characteristic of the Iron Age settlements (Figure 9) and this typology will evolve into the rectangular plan];

b. buildings with roof and wall in vegetable materials, with circular (conical) or rectangular plan [in this type of construction entirely of vegetable material, the cover extends to the soil and constitutes a primitive form, originating from the Paleolithic (Veiga de Oliveira et al. 1994)];

c. Buildings entirely of vegetable materials with distinguished wall and roof. With rectangular plan, these buildings appear in several coastal areas of Portugal. The huts of Carrasqueira village, located in the Sado estuary, near Alcácer do Sal, in the south of Lisbon here presented in detail, are of this last type (Figure 10).

\footnotetext{
${ }^{3}$ The chimney has become indispensible for, otherwise than in the lagoon typology, the fire was used not only for cooking but also and mainly for heating up the room during the cold winters.
} 
Figure 9. Reconstitution of House with Thatch Roof on "Citânia de Briteiros", near Guimarães, Portugal

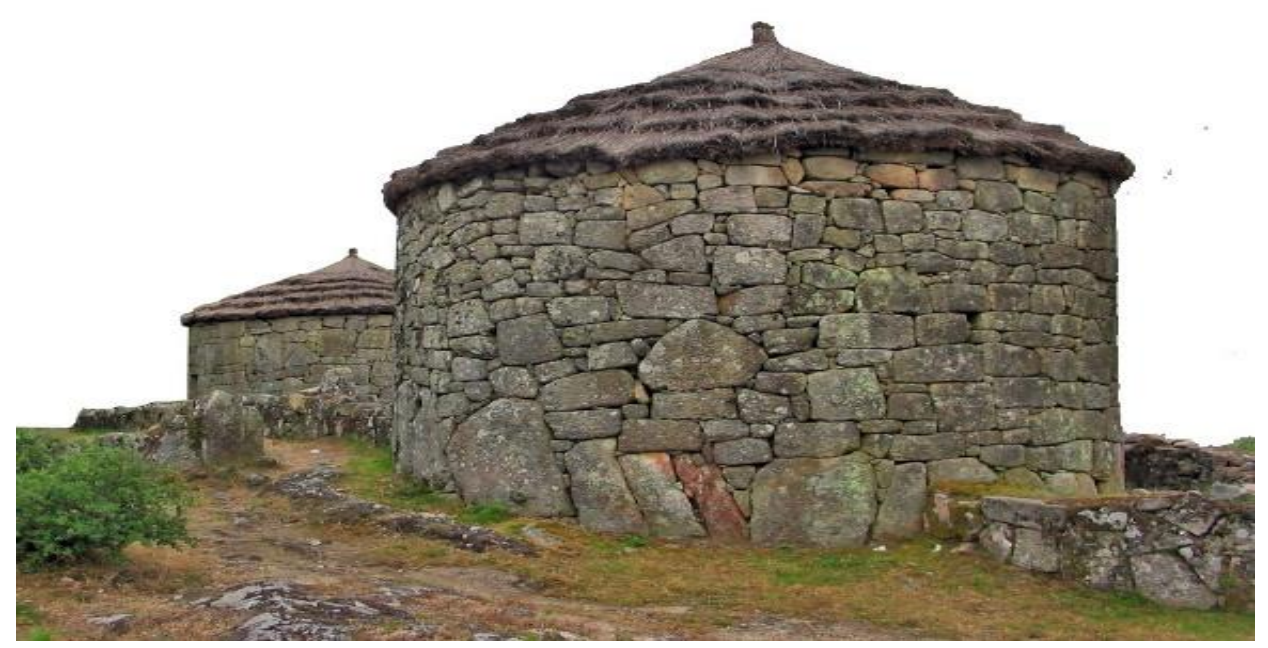

Source: Picture by F. Amorim.

Figure 10. Map of Portugal Showing the Location of Alcácer do Sal

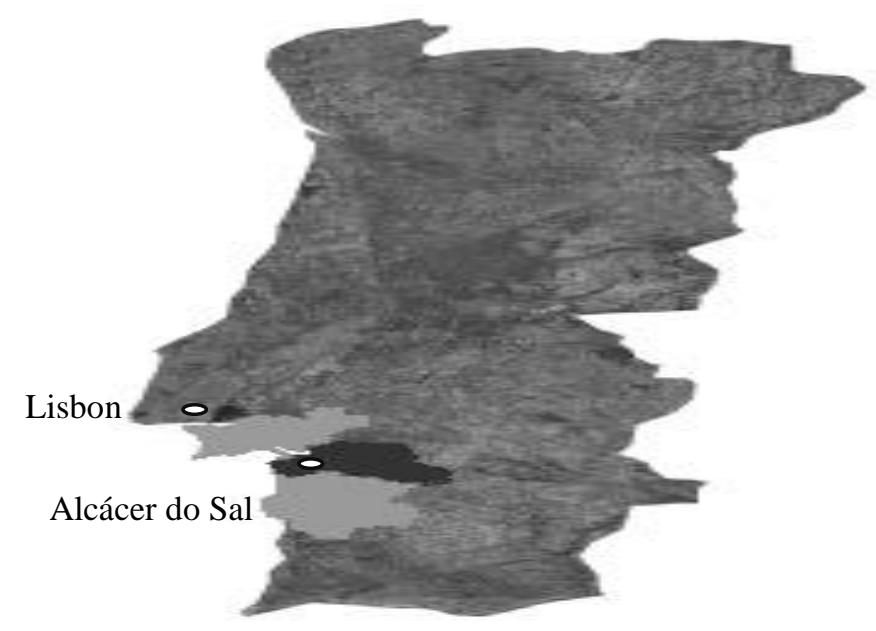

Source: Prepared by P. Mendonca and F. Amorim.

\section{Location of Carrasqueira}

In the XIX century the Carrasqueira huts arose from the need to build shelters for workers in rice paddies, although the location, a few of them may also be connected to the fishing resources. The first fisheries had already begun in the early sixteenth century, so some huts could begin to emerge already at this time (Veiga de Oliveira et al. 1994). The workers long settled till some families ended by permanently establish in this land; since the landlord forbade them to build with durable materials, they adopted the thatch to cover both roof and walls. The implementation of the huts was designed according to the 
morphological characteristics of the plot. The ground should be flat and with little vegetation. Higher points were avoided, due to their excessive sun and wind exposure. Lower areas were also more fertile and abundant in resources. The openings were designed to capture the sun and promote ventilation, necessary to keep the vegetable coating materials free of any fungus or rot (Pires 2013) (Figure 11).

Figure 11. Carrasqueira Hut

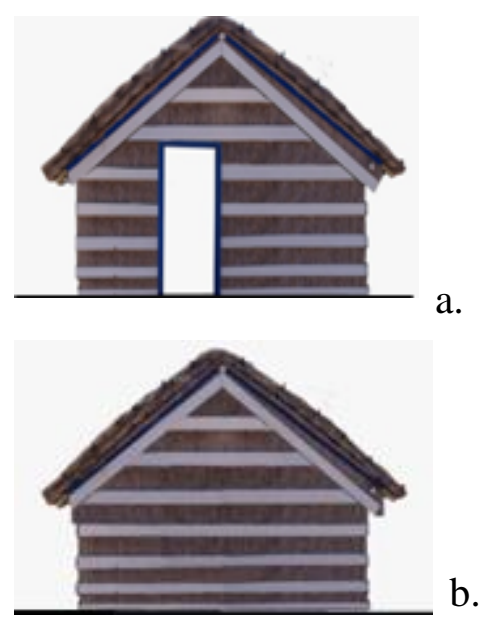

a. Entrance façade

b. Back façade

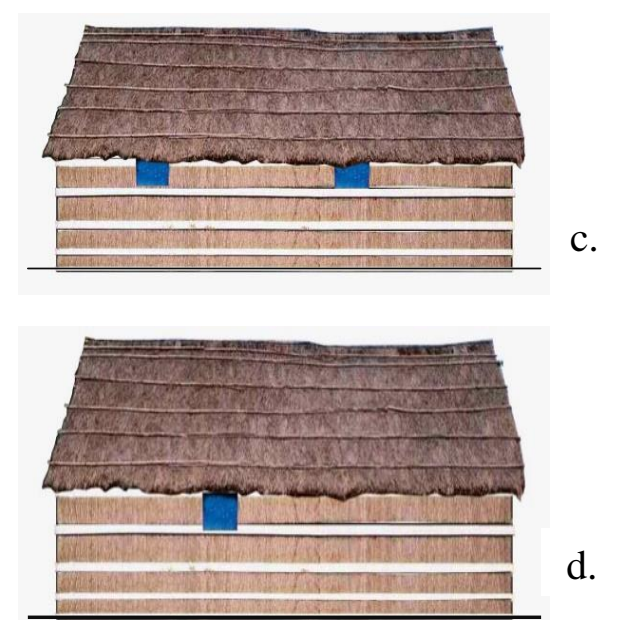

c. Side façade

d. Side façade

Source: Prepared by P. Mendonca and F. Amorim.

\section{Typology of the Carrasqueira Hut}

The entrance could be made from the top or the side façades, but always facing east (Figure 12). Entering from the top allows the space to be more fluid and unitary. When entering from the side, the space is automatically divided into two rooms, facilitating the distribution. The huts were of reduced dimensions without partitioning or with only two compartments. In the first case, the surface area ranged from 20 to $30 \mathrm{~m}^{2}$ and the spaces were defined by the furniture (Pires 2013). The area near the entrance had a more public character, where eating and living allowed communion between indoor and outdoor spaces. Furthest from the entrance were the sleeping, dressing and hygiene areas, of a more private character. 
Figure 12. Plan of a Carrasqueira Hut with Schemes of Entrance and Distribution

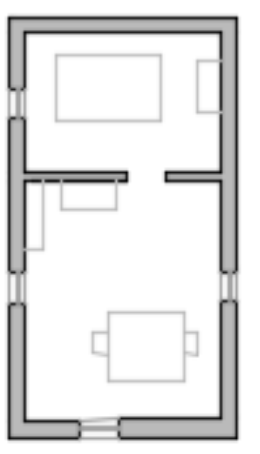

E+口
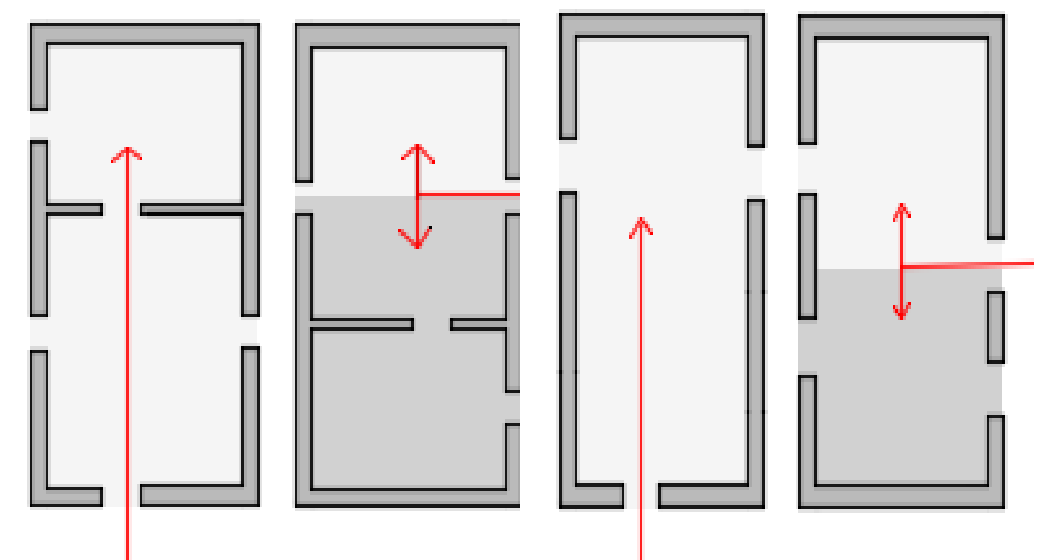

Source: Prepared by P. Mendonca and F. Amorim.

\section{$\underline{\text { Building Construction Process }}$}

The plan is rectangular and the structure of these buildings is in wood. The walls and roof are both in thatch, however the coverage is made using a thinner stem. The thatch can be attached to the wooden structure stitching it into small bundles wired to reeds or it can be spread over the surface and secured with a board or rod that is attached to the main structure by ropes or nails, being this technique called "valadio" (Pires 2013). Inside, the walls can be plastered with lime, covered with reeds or with wooden boards, (Figure 13). When being plastered, a thinner thatch made with Corema Album plant is superposed and subsequently plastered with earth and lime slurry. Another option could be to place rods horizontally attached to the main structure and then placing the earth plaster and lime (Bruno and Faria 2010). The openings have a timber frame. Doors have a wicket and the windows, of small size, have interior shutters. They can be painted, usually in blue or red, and the boards or rods that support the culm are painted in white, both outside and inside. It has no chimney, as there was no kitchen inside, and the floor was in compacted soil or in clay tiles. (Veiga de Oliveira et al.1994). 
Figure 13. Different Thatch Wall Types Used in Carrasqueira Huts
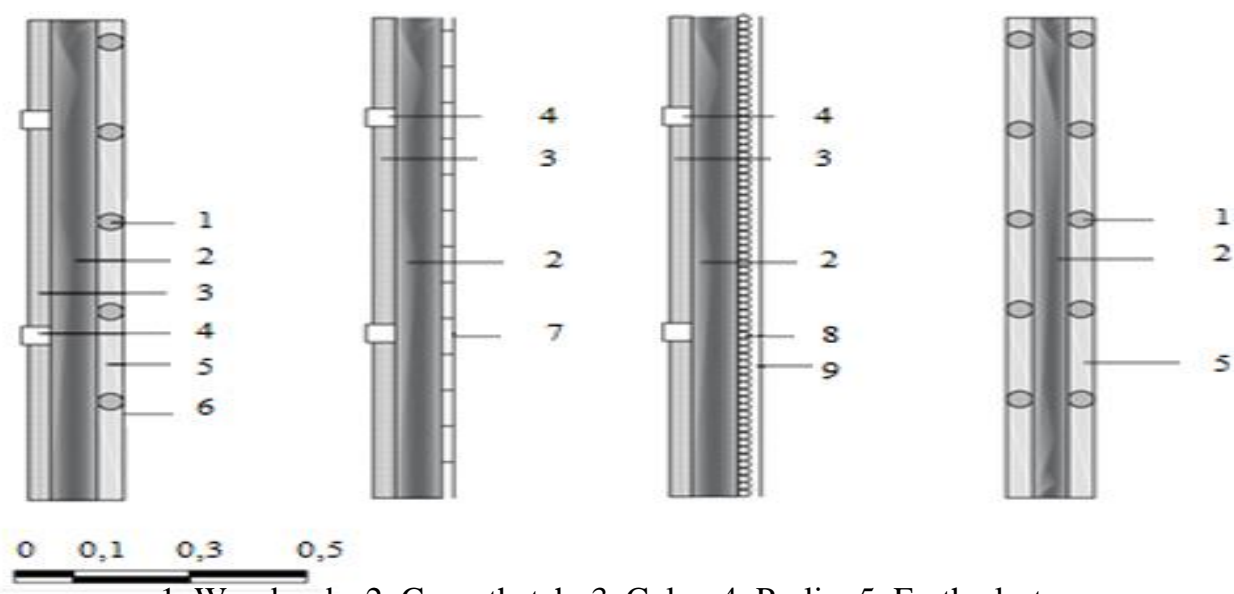

1. Wood rods; 2. Grass thatch; 3. Culm; 4. Purlin; 5. Earth plaster; 6. Lime slurry; 7.Boards; 8. Corema Album thatch; 9. Earth plaster

Source: Drawing by P. Mendonca and F. Amorim.

\section{Discussion}

\section{Casone’s Performances}

Although the Casone does not respond efficiently to the safety, the security and the environmental safeguard ${ }^{4}$, due to absence of sufficient windows and chimney and to plan disposition which does not separate the rooms, and then is very critical as far as quality of life and liveability are concerned, nonetheless insulation $^{5}$ and breathiness of the envelope in marsh cane increase greatly the thermal performances. The country Casone has even a better performance, thanks to the rammed earth. Moreover the benefit derived from the location of the chimney under wind, besides reducing the fire hazard for the roof, it also allows to improve the air quality in the dwelling, so avoiding the smoke in the units. As far as the environmental safeguard, the marsh cane and the straw, being vegetable fibers, allow to label the fabric as sustainable, for the high naturality of the construction material: in fact the environmental impacts are very low in any stage of the life cycle; during the pre-production and production stages there are almost no transformation processes, and with very few energy; in the site stage easy constructive technologies are required, for the dry assembling is used and dry joints or ropes are selected for the knots; finally in the stage of disuse, it is possible to recycle and reuse all the products ${ }^{6}$. Some improvements proposed over time in the country residence create advantages in

\footnotetext{
${ }^{4}$ According to the Italian standard UNI 8290.

${ }^{5}$ The thermal conductivity for the swamp cane is evaluated around $0.056 \mathrm{~W} / \mathrm{mK}$.

${ }^{6}$ Biological end of life are materials designed to flow optimally in the biological metabolism are biological nutrients. These materials are biodegradable, are designed to be used and safely returned to the environment to nourish living systems.
} 
the quality of life and in the users' comfort: for example thermal transmittance has been improved by substituting the vegetable fibers with the clay wall; or the elevation of the roof base allowing the use of barn as buffer space, while the inclusion of the windows - although small and few - allows the air changes, so gaining a better quality in dwelling. The result of this comparison shows that the introduction of synthetic materials, such as the cooked bricks and the metal sheet has produced a de-naturalization of the identity relationship that the construction had with the context, a downgrading of the ecology of the fabric and it has cracked the balance between man and nature, so dear to the casoniere, the countrymen and the fishermen once living in these architectures. "The primitive man which lives in the lagoon is able to read these balances, can gather the complexity of the ecological relationships in which he is included and succeeds to be integral part of, without compromising, them. It cannot be said the same for the modern man, maybe more technological advanced, but more analphabetic in regards to the ecological wisdom ... than the ancient man; or better the today man is often provider of an exogenous technology, independent from the environmental context, so going against the "soft technology" of the lagoon man" (Franzin 2004).

The technological and material transformations with bricks, steel and tiles have altered the eco-sustainable relationship between the built heritage and the context, which once identified the main character of these fabrics. Even though the two living typologies were belonging to different languages, nevertheless they employ the same construction principles. According to the literature the best orientation is the strength point of the inhabiting typology, therefore the Casoniere used to well orient the fabric so as to avoid the cold wind of the Bora. The country fabrics were long and rectangular while the lagoon ones were elliptic. The advantages of a good orientation (North-North East /SouthSouth -West) were in fact great, such as:

- A reduction of inconveniences due to a climatic discomfort, and a greater aerodynamic structure which, avoiding the exposure to wind, can also prevent the roof fall, very usual in the lagoon type (Figure 14 ).

- Reduction of fire hazard and improvement in the air quality in the internal rooms, through the localization of the chimney in under- wind places, usually a solution adopted in the country Casoni.

Improving the air quality by means of promotion of natural ventilation, in the cases of framed windows (Figure 15). 
Figure 14. Best Orientation and Wind Analysis of Lagoon Casoni

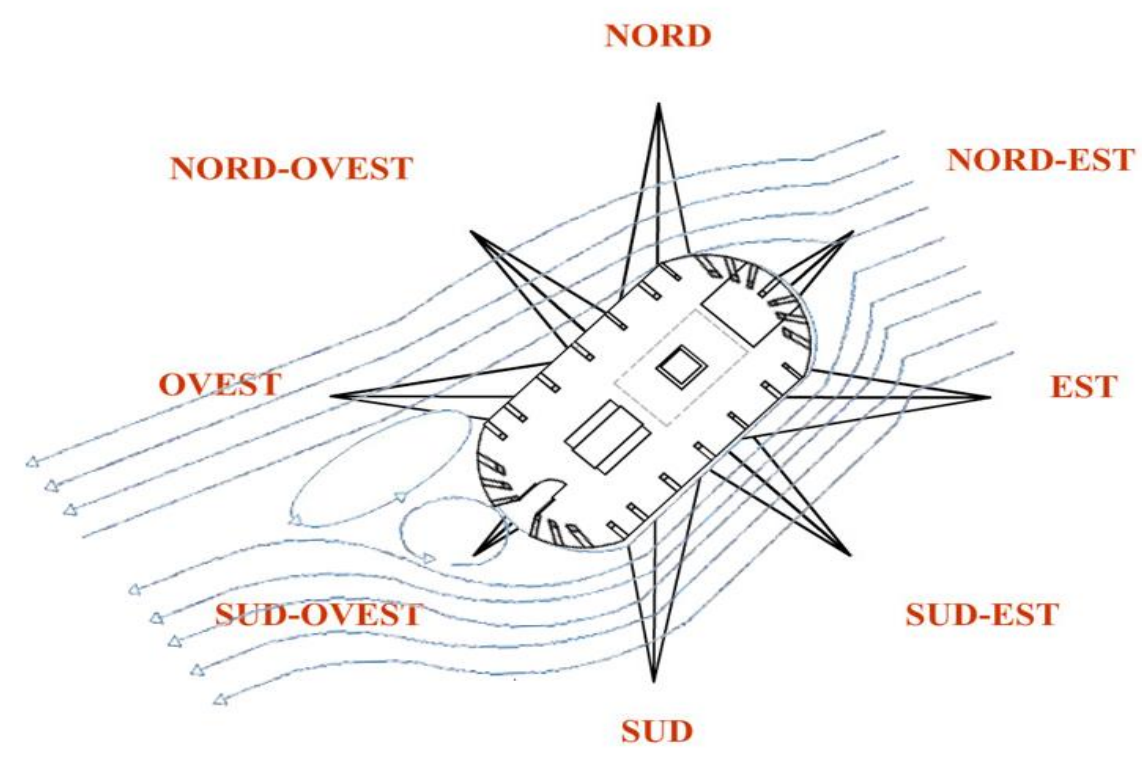

Source: Prepared by N. Mastrangelo.

Figure 15. The Country Casone: Façade Little Windows

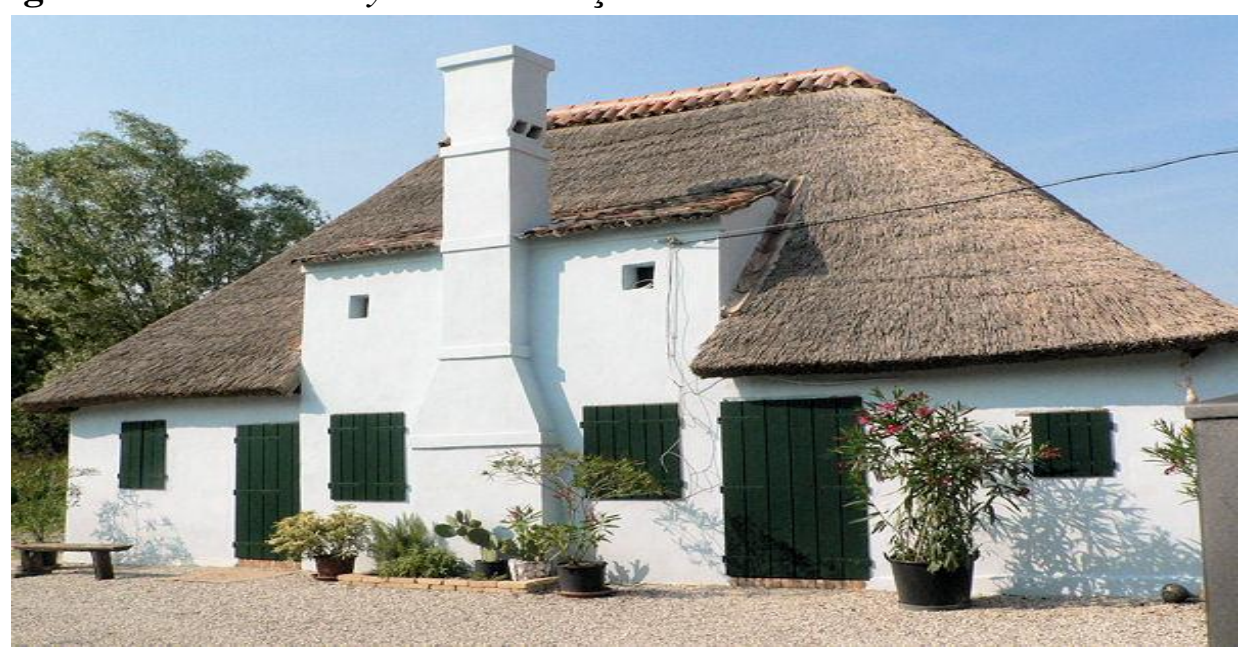

Source: Borgo-Italia, the Virtual Magazine. Retrieved from bit.ly/1Pt9lai.

\section{Conclusion}

The comparison between the Italian and the Portuguese case studies has shown the difference in the construction and in the typology of the buildings, while had focused on some similarities. The differences are the followings: use as fishermen' and countrymen' residence; models of technologies employed, use of earth as composition of the walls; material selection; location of the straw. In some traditional dwellings the straw is employed only for the roof, whilst in some others the vegetable fibres are used also for external walls and partitions. Usually the Portugal is colder, wetter and more windy than Italy, 
but being the North Italian climate slightly different from the South Portuguese one, the Casoni and the Carrasqueira huts show similar bioclimatic behaviour; in fact both these traditional constructions appear well protected from the winter and sea factors: the main factor producing this benefit is the employment of straw and other vegetable fibres in a suitable location, besides the place and scarcity of the windows, which allow the heat to be saved as much as possible, either there is a kitchen (as in the Italian case), or there is not. Concluding, the use of the straw in traditional dwellings can become model for new uses of this material as sustainable, insulating and highly healthy system of construction, if the lacks and the disadvantages will be substituted by more modern technologies, whilst at the same time the great potential of ecological properties will be saved.

\section{References}

Bruno P, Faria P (2010) Cabanas de materiais vegetais na Herdade da Comporta. Tradição construtiva e novas abordagens [Cabanas plant materials in Herdade da Comporta. Building tradition and new approaches]. Terra em Seminário. Argumentum, Lisbon, 240-243.

Cipullo G (2013) Traditional technologies in Japan:comparative reading of GasshoZukuri an a venetian Casone. Thesis, Department of Architetture, Univerity "Federico II" of Naples.

Franzin R (2004) I casoni dalle lagune di Caorle e Bibione a Cavarzere [Casoni from the lagoons of Caorle and Bibione in Cavarzere], Provincia di Venezia, nuova dimensione, Portoguaro.

May J, Reid A (2010). Architetture senza architetti. Guida alle costruzioni spontaneee di tutto il mondo,[ Architecture without architects. Guide spontaneee buildings around the word]. Milano: Rizzoli.

Mendonça P (2005) Habitar sob uma segunda pele: estratégias para a redução do impacto ambiental de construções solares passivas em climas temperados [Home a second skin : strategies to reduce the environmental impact of passive solar buildings in temperate climates]. PhD thesis. University of Minho, Faculty of Engineering.

Pires M d S (2013) Arquitectura das Cabanas do Estuário do Sado: Formas e Vivências dos Espaços Vernaculares [Architecture of the Huts of the Sado estuary: Forms and experiences of Vernacular Spaces]. Master's thesis. Faculty of Architecture, Technical University of Lisbon.

Tieto P (1979) I casoni Veneti [The Veneto Casoni]. Padova: Panda Edition. Retrieved from bit.ly/1Q7wzYf.

Veiga De Oliveira E, Galhano F, Pereira B (1994) Construções primitivas em Portugal [Primitive buildings in Portugal]. $3^{\text {a }}$ Edition. Lisbon: Dom Quixote. ISBN: 972-20-0196-5. 
